\title{
Correction to: Gut microbial characteristics of adult patients with allergy rhinitis
}

\author{
Libing Zhu ${ }^{1}$, Feng $X u^{2}$, Wenrong Wan ${ }^{2}$, Bin Yu ${ }^{3}$, Lin Tang ${ }^{3}$, Yimin Yang ${ }^{4}$, Yanling Du ${ }^{5}$, Zhangran Chen ${ }^{6,7,8^{*}}$ (D) \\ and Hongzhi $X u^{6,7,8^{*}}$
}

\section{Correction to: Microb Cell Fact (2020) 19:171}

https://doi.org/10.1186/s12934-020-01430-0

Following publication of the original article [1], the authors identified three errors: two in the author name of Hongzhi Xu and Yimin Yang, and one in the caption of Fig. 1.

The author names Hongzhi $\mathrm{Xu}$ and Yimin Yang had been incorrectly spelled as 'Hongzhu Xu' and 'Yiming Yang.'

While Fig. 1 had been (incorrectly) captioned with 'Comparisons of bacterial diversity between $\mathrm{AR}$ and
non-AR patients. a The bacterial á diversity indexes comparison including Chao1, J and Shannon. Letters indicate the ANOVA groupings. b Differences in bacterial community structures between samples from AR and non-AR'

The names and caption have been corrected in the original article.

Please also find the corrected author names and figure caption in this correction article.

The authors apologize for any inconvenience caused. is not included in the article's Creative Commons licence and your intended use is not permitted by statutory regulation or exceeds the permitted use, you will need to obtain permission directly from the copyright holder. To view a copy of this licence, visit http://creativeco mmons.org/licenses/by/4.0/. The Creative Commons Public Domain Dedication waiver (http://creativecommons.org/publicdomain/ zero/1.0/) applies to the data made available in this article, unless otherwise stated in a credit line to the data. 

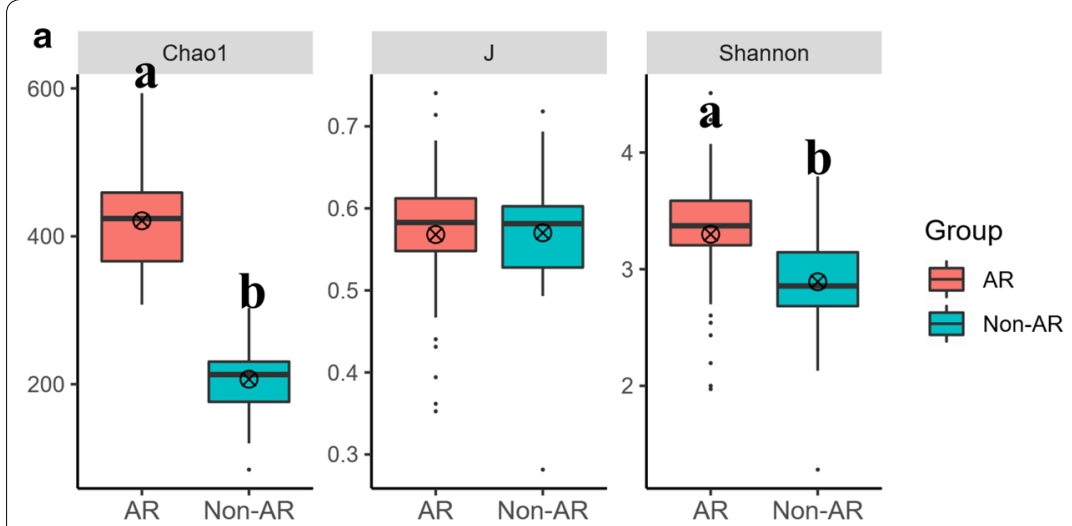

b
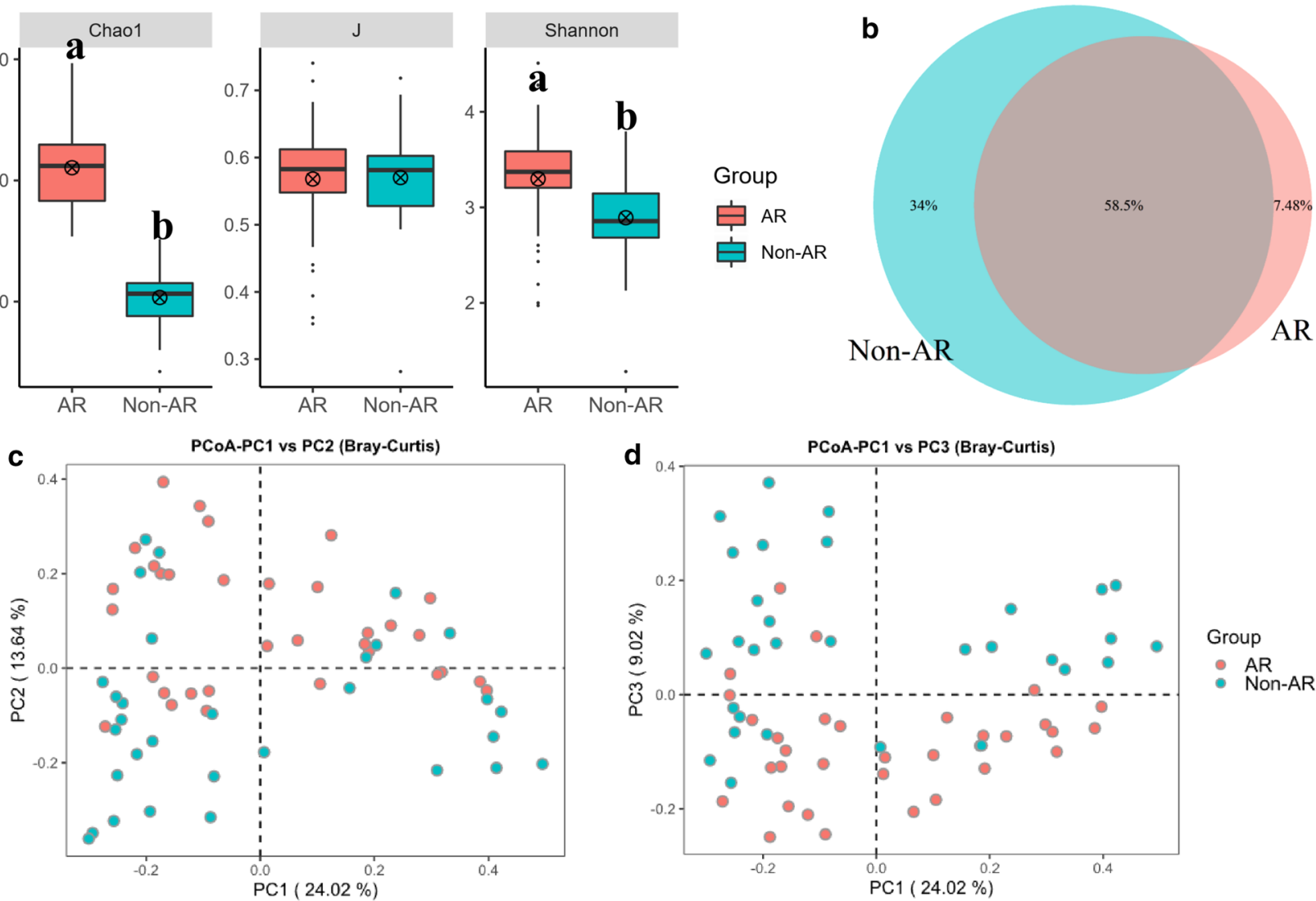

d

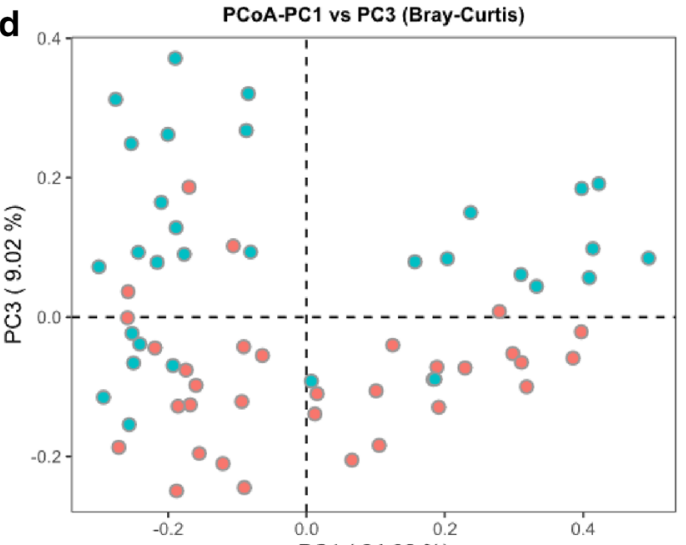

Group

- $\quad$ Non-AR

Fig. 1 Comparisons of bacterial diversity between AR and non-AR patients. a The bacterial a diversity indexes comparison including Chao 1, J and Shannon. Letters indicate the ANOVA groupings. $\mathbf{b}$ Differences in bacterial community structures between samples from AR and non-AR. c The PCOA analysis revealing the bacterial communities between AR and non-AR in PCoA1 vs PCoA2 axis. $\mathbf{d}$ PCoA1 vs PCoA3 axis

\section{Author details}

${ }^{1}$ Department of Traditional Chinese Medicine, School of Medicine, Xiamen University, Xiamen, China. ${ }^{2}$ Internal Medicine Department of Traditional Chinese Medicine, Xiamen Hospital of Traditional Chinese Medicine, Xiamen, China. ${ }^{3}$ Department of Otorhinolaryngology, Xiamen Hospital of Traditional Chinese Medicine, Xiamen, China. ${ }^{4}$ Department of Pediatrics, Xiamen Hospital of Traditional Chinese Medicine, Xiamen, China. ${ }^{5}$ Department of Acupuncture and Tuina, Fujian University of Traditional Chinese Medicine, Fuzhou, China. ${ }^{6}$ Department of Digestive Diseases, School of Medicine, Xiamen University, Xiamen, China. ${ }^{7}$ Department of Gastroenterology, Zhongshan Hospital, Xiamen University, Xiamen, China. ${ }^{8}$ Institute for Microbial Ecology, School of Medicine, Xiamen University, Xiamen, China.

Published online: 08 October 2020

\section{Reference}

1. Zhu L, Xu F, Wan W, Yu B, Tang L, Yang Y, Du Y, Chen Z, Xu H. Gut microbial characteristics of adult patients with allergy rhinitis. Microb Cell Fact. 2020;19:171. https://doi.org/10.1186/s12934-020-01430-0.

\section{Publisher's Note}

Springer Nature remains neutral with regard to jurisdictional claims in published maps and institutional affiliations.

Ready to submit your research? Choose BMC and benefit from:

- fast, convenient online submission

- thorough peer review by experienced researchers in your field

- rapid publication on acceptance

- support for research data, including large and complex data types

- gold Open Access which fosters wider collaboration and increased citations

- maximum visibility for your research: over $100 \mathrm{M}$ website views per year

At BMC, research is always in progress.

Learn more biomedcentral.com/submissions 